\title{
doi:10.2489/jswc.65.6.142A \\ RESEARCH USDA water quality projects and the National Institute of Food and Agriculture Conservation Effects INTRODUCTION Assessment Project watershed studies
}

\author{
Deanna L. Osmond
}

$\mathbf{T}$ he first major federally-funded effort to relate effects of conservation practices to water quality was the Black Creek Project in northeastern Indiana beginning in 1975 (USEPA 1977). From 1978 to 1982, United States Department of Agriculture (USDA) and US Environmental Protection Agency (USEPA) conducted the Model Implementation Program (MIP) to demonstrate and study the effects of addressing agricultural nonpoint source problems through Section 208 of the Clean Water Act (CWA) (NWQEP and Harbridge House 1983). Building on these early efforts, a much larger USDA- and USEPA-sponsored nonpoint source (NPS) pollution control program, The Rural Clean Water Program (RCWP), began in 1980 as an experiment to combine land treatment and water quality monitoring to document NPS control effectiveness across the country (Gale et al. 1993). The objectives of the RCWP were (1) to achieve improved water quality in the project area in the most cost-effective manner possible in keeping with the provision of adequate supplies of food, fiber, and a quality environment; (2) to assist agricultural landowners and operators in reducing agricultural NPS water pollutants and improving water quality in rural areas to meet water quality standards or water quality goals; and (3) to develop and test programs, policies, and procedures for the control of agricultural NPS pollution.

USDA, in consultation with USEPA, funded the 21 experimental watershed projects (\$64 million) that became the RCWP. These projects were conducted in Alabama, Delaware, Florida, Idaho, Illinois, Iowa, Kansas, Louisiana, Maryland, Massachusetts, Michigan, Minnesota, Nebraska, Oregon, Pennsylvania, South Dakota, Tennessee/Kentucky, Utah, Vermont, Virginia, and Wisconsin. The

Deanna L. Osmond is professor and Department Extension Leader at the Department of Soil Science, North Carolina State University, Raleigh, North Carolina. projects represented a wide range of geophysical settings, pollution problems, and water quality impairments. Each project involved the implementation of best management practices (BMPs) to reduce NPS pollution and some level of water quality monitoring to evaluate the effects of the land treatment. Land treatment in each project was targeted to critical areas, i.e., sources of nonpoint source pollutants identified as having significant impacts on the impaired water resource. Landowner participation was voluntary, with cost sharing and technical assistance offered as incentives for implementing BMPs. Landowners receiving cost-share assistance were contracted to implement BMPs, with the length of the contract depending on the practice being implemented. Although some water quality monitoring was performed in all 21 projects, five projects (in Florida, Illinois, Pennsylvania, South Dakota, and Vermont) were funded for intensive comprehensive monitoring and evaluation to fully investigate the relationships between land treatment and water quality response. Many of the RCWP projects made significant contributions to the body of knowledge regarding NPS pollution, NPS control technology, BMP effectiveness, and the effectiveness of voluntary cost-share programs aimed at assisting producers in reducing agricultural NPS pollution. Possibly the most important contribution made by the RCWP was the advancement of our understanding of how to plan, implement, manage, and monitor voluntary agricultural NPS pollution control efforts.

In many RCWP projects, even the intensively monitored projects, water quality benefits were not documented because (1) impacts of changes in agricultural activities were masked by nonagricultural pollutant sources, (2) the water quality problem was not correctly defined, (3) the extent (area) and strength of land treatment was inadequate, (4) monitoring designs were not adequate to document water quality improvements, or (5) an insufficient period of time had elapsed since initiation of land treatment to allow measurement of water quality changes, especially in cases where recycling of pollutants stored in aquatic sediments masked reductions in pollutant loading from a watershed. However, the work conducted during the RCWP provided many important lessons learned (Gale et al. 1993) and spawned new generations of agricultural water quality projects.

From 1991 to 1995, the USDA implemented the Water Quality Program to provide producers with the assistance to meet environmental concerns and protect water quality (Meals et al. 1996). Ninety Hydrologic Unit Area (HUA) projects were designed to improve or protect water quality cost-effectively by reducing agricultural nonpoint source pollution. Lessons learned from some case studies of these projects confirmed the difficulties involved in relating land treatment to water quality that had been highlighted in the RCWP projects.

In 1990, three federal agencies-the USEPA, the USDA, and the United States Geological Survey (USGS)—established the Management Systems Evaluation Area (MSEA) Project with sites in Iowa, Minnesota, Missouri, Nebraska, North Dakota, Ohio, South Dakota, and Wisconsin to evaluate the impact of farming systems on water quality. The project focused on field and plot research that is shared with producers so they can respond voluntarily to water quality requirements while maintaining or increasing crop productivity and profitability.

There are two current watershed programs funded by the federal government that again seek to relate water quality improvements to changed agricultural practices and land use - the USEPA Section 319 National Nonpoint Source Monitoring Program (NNPSMP) and the USDA Conservation Effects Assessment Project (CEAP).

The USEPA 319 NNPSMP has been providing credible documentation of controlling nonpoint sources and improving the technical understanding of nonpoint 
source pollution and the effectiveness of nonpoint source control technology and approaches (Spooner et al. 2009). The selection criteria for selection of Section 319 National Monitoring Program projects are focused on projects that have a high probability of documenting water quality improvements from nonpoint source controls over a five- to ten-year period.

Project selection attempts to be rigorous and requires documentation of the water quality problem; a comprehensive watershed description; a delineated critical area based on the primary pollutants causing the impairment; a watershed implementation plan that uses appropriate conservation practices; quantitative and realistic water quality and land treatment objectives and goals; high level of expected implementation and landowner participation; a clearly defined nonpoint source monitoring program objectives; water quality and land treatment monitoring designs that have a high probability of documenting changes; well-established institutional arrangements and multiyear, up-front funding for project planning and implementation; and effective and ongoing information and education programs. Many of these projects have been able to demonstrate improvements in water quality due the implementation of conservation practices.

The CEAP effort is a multiagency (USDA Natural Resources Conservation Service, USDA Agricultural Research Service, National Institute of Food and Agriculture (NIFA), and Farm Service Agency (FSA), along with many others) endeavor with the overarching goal of improving the efficacy of conservation practices and programs by quantifying conservation effects and providing the science and education base needed to enrich conservation planning, implementation, management decisions, and policy (Duriancik et al. 2008; Maresch et al. 2008).

Multiple scales (field, watershed or landscape, and regional or national) and land uses (croplands, grazing lands [both pasture and range], and wetlands) are assessed in CEAP as multiple resource concerns-water quality and availability, soil quality, and wildlife. The ultimate output of CEAP results will be to guide USDA policy vis-à-vis conservation planning and implementation.

Currently, 17 projects covering 20 watersheds comprise the NIFA CEAP projects (USDA NIFA 2010). The goal of these watershed studies is to determine the measurable effects of agricultural conservation practices on water quality patterns and trends in surface and/or ground water at the watershed scale. Thirteen of these projects focus on cropland agriculture, while five focus on rangelands.

The 13 CEAP watershed cropland projects were funded in fiscal years 2004 to 2006 to evaluate the watershed-scale water quality effects of conservation practices, especially with respect to understanding how the suite of conservation practices, the timing of these activities, and the spatial distribution of these practices throughout a watershed influence their effectiveness for achieving locally defined water quality goals. The NIFA CEAP cropland projects are Lower Calapooia River watershed (Oregon), Cannonsville Reservoir watershed (New York), Central Platte Natural Resources District (Nebraska, a ground water study), Cheney Lake watershed (Kansas), Eagle Creek watershed (Indiana), Goodwater Creek watershed (Missouri), Lincoln Lake watershed (Arkansas), Little Bear River watershed (Utah), Little River watershed (Georgia), Paradise Creek watershed (Idaho), Rock Creek watershed (Ohio), Spring Creek watershed (Pennsylvania), Walnut Creek watershed (Iowa), Sny Magill watershed (Iowa/ Wisconsin), and South Fork of the Iowa River (Iowa).

Projects are expected to evaluate the impacts of interactions among conservation practices and their biophysical setting on water quality at the watershed scale. In addition, CEAP projects are expected to evaluate social and economic factors influencing implementation and maintenance of conservation practices. Most of these projects are complete and they have generated many publications and presentations that address the physical, social, and economic effects of conservation practices relative to water quality.

In the current issue of the Journal of Soil and Water Conservation, twelve papers are presented from the NIFA CEAP research, representing over half of the 13 projects. Much of this information was derived from empirical evidence, while some was obtained through modeling efforts. These papers show a wide range of research and modeling strategies utilized by the CEAP projects and are about equally representative of the major research categories-social and economic dimensions, modeling, water quality results, and land treatment effects.

\section{SOCIAL AND ECONOMIC DIMENSIONS}

In the article "Determinants of the adoption of conservation practices by farmers in the Northwest Wheat and Range Region,"Tosakana et al. (2010) have summarized a producer survey conducted with wheat farmers in western Idaho and eastern Washington. The authors found that producers were interested in adopting gulley plugs and buffers, although actual adoption was dependent on the apparent effectiveness of the conservation practice. As other surveys have found, producers with larger farms had greater conservation practice adoption rates.

Jackson-Smith et al. (2010) collected conservation practice type and location information for the period of six years. These were federally funded best management practices and the information is presented in "Measuring conservation program best management practice implementation and maintenance at the watershed scale" (Jackson-Smith et al. 2010). A field survey of conservation practice recipients was then used to ascertain the discrepancies between the records and actual implementation, utilization, and maintenance of the best management practices. Significant variation of the surveyed conservation practices existed relative to documentation, implementation timing, location, and maintenance of these practices. Implications from this very unique study suggest that conservation practice effectiveness may be lower than what federal and/or state records suggest due to some of the issues identified.

In the paper" Impact of crop rotations on optimalselection of conservation practices for water quality protection" Rabotyagov et al. (2010) explore the relationship 
between conservation practice costs and effectiveness, with land use practices and changes. Researchers used detailed crop production budgets, water quality models, and optimization tools (evolutionary algorithms - a class of stochastic optimization methods) to determine a watershed-level pollution abatement cost curves with land use changes. Practices such as conservation tillage, buffer strips, grassed waterways, and land retirement were used. As pollutant load reduction needs increased due to higher agricultural land use, the mix of conservation practices was greater. However, this mix varied based on the pollutant of concern. Watershed managers will need to adapt their conservation tools as land uses change.

\section{MODELING}

Jha et al. (2010) in their paper "Targeting land-use change for nitrate-nitrogen load reductions in an agricultural watershed" calibrated SWAT (Soil and Water Assessment Tool) and then used it to compare land use change and nitrate-nitrogen losses in a typical Iowa watershed, Squaw Creek. Results of the modeling demonstrated that nitrate-nitrogen could be reduced by changing the type and location of land use. Transforming Conservation Reserve Program (CRP) land back to row crops increased nitrate losses. In addition, nitrate reduction was greater when grasslands were installed on highly erodible lands (HEL) rather than uplands or floodplains. This team demonstrated the usefulness of SWAT in targeting conservation practices to critical areas within the watershed.

In Georgia, Cho et al. (2010) modeled the Little River Experimental watershed using SWAT with the goal of evaluation conservation practices. Conservation practices consisted of erosion control practices (grassed waterways, terraces, contour farming, and conservation tillage), nutrient reduction $(30 \%$ nitrogen $[\mathrm{N}]$ and $30 \%$ phosphorus $[\mathrm{P}]$ ), and intact riparian buffers. Three modeling strategies were used by adding conservation practices randomly, prioritizing location based on stream order, or targeting areas with the greatest pollutant loads. The targeting conservation practices strategy resulted in the most rapid improvement in water quality. Better reduction of both nutrients and sediments was obtained from the intact riparian buffers, which are probably the most important conservation practice in this watershed.

Chaubey et al. (2010) used SWAT and a combination of 171 conservation practices to derive the "Effectiveness of best management practices in improving water quality in a pasture-dominated watershed." By modeling a combination of grazing and pasture management, riparian and buffer zones, and poultry litter applications over a 25-year weather period, results indicated that greater amounts of litter significantly increased $\mathrm{N}$ and $\mathrm{P}$ losses. Not surprising, pasture management was very important in that overgrazed pastures also increased nutrient losses. Seasonal variations indicated that fall application of manure was more detrimental than spring or summer. Based on SWAT, managing litter, pasture cover, and riparian areas gave the greatest protection to water quality.

\section{WATER QUALITY ANALYSIS}

Richards et al. (2010) were able to document extremely high loads of total $\mathrm{P}$, dissolved reactive $\mathrm{P}$, and total Kjeldahl $\mathrm{N}$ in the Maumee and Sandusky rivers during water year 2007 due to a long-term 30 -year water quality record. High pollutant loading was a function of record rainfalls, particularly during the fall, and changes in phosphorus-containing fertilizer timing (fall) and placement (surface). Although Richards has been able to document significant reductions in total suspended sediments and phosphorus over the 30-year record due to large increases in conservation tillage, dissolved reactive phosphorus has increased due to changes in the fertilizer management. Thus, the very high loads in 2007 were a function of both weather (high discharge) and changes in the availability of the pollutant (higher dissolved reactive phosphorus concentrations).

Extremely high erosion losses have occurred in the Palouse region of the United States. For over 30 years, researchers and extension personnel have worked to change tillage behavior. Brooks et al. (2010) documented reductions in sedi- ment loss, primarily due to the success of conservation tillage, in their paper "Long-term sediment loading trends in the Paradise Creek watershed." Several different levels of data analysis suggest that current sediment losses are almost entirely from historical sediments and streambanks. In addition, as sediment has been reduced in the agricultural areas, there has been a concurrent increase from the urban areas. However, the net sediment load has declined over the past 28 years.

\section{LAND TREATMENT}

Researchers monitored a pair of watersheds in northeast Iowa during almost a 20-year period (Gassman et al. 2010) to determine the effectiveness of conservation practices. The authors compared the treated watershed to the control watershed in their paper "Conservation practice establishment in two northeast Iowa watersheds: Strategies, water quality implications, and lessons learned" and found that pollutants and habitat changed in somewhat surprising directions for the treated watershed-turbidity declined by $41 \%$, sediment only declined by $7 \%$, $\mathrm{NO}_{\mathrm{x}}-\mathrm{N}$ (nitrate-nitrogen plus nitritenitrogen) increased by $15 \%$, and fish habitat improved in both watersheds. From this research, the authors have gathered important lessons learned about water quality and conservation practices.

In the Catskills Mountains of New York State, exclusionary fencing is an important conservation practice used by dairy farmers. In "A multivariate analysis of covariance to determine the effects of near-stream best management practices on nitrogen and phosphorus concentrations on a dairy farm in the New York Conservation Effects Assessment Project watershed," Flores-Lopez et al. (2010) demonstrated using paired field design that stream fencing with a width of $5 \mathrm{~m}$ (16 ft) and cattle crossing (same width) reduced annual soluble reactive $\mathrm{P}$ loading by $27 \%$, but did not reduce $\mathrm{NO}_{3}-\mathrm{N}$, probably due to large carbon availability from the dairy waste and saturated soils, which together facilitated denitrification.

In "Effects of long-term soil and crop management on soil hydraulic properties for claypan soils," Mudgal et al. (2010) 
sampled soils from the same soil series (Mexico silt loam) that were managed differently — one had been in continuous cultivation for over 100 years and the other was native tallgrass prairie. The $\mathrm{K}_{\text {sat }}$ value was 57 times larger for the tallgrass prairie management. Not surprisingly, there was a significant difference in pore-size distribution and bulk density, with the prairie site bulk density averaging $0.81 \mathrm{~g} \mathrm{~cm}^{-3}$ $\left(55.6 \mathrm{lb} \mathrm{ft}^{-3}\right)$ and the cultivated site averaging $1.44 \mathrm{~g} \mathrm{~cm}^{-3}\left(89.9 \mathrm{lb} \mathrm{ft}^{-3}\right)$. Management and their effects on soil properties must be accounted for when using soil property data in models.

Northwest Arkansas has been experiencing rapid changes in land use from pasture-based agriculture to larger urban areas. As a consequence, the Arkansas NIFA CEAP project had to account for land use changes and concurrent conservation practice implementation (Gitau et al. 2010). The paper "Impacts of land-use change and best management practice implementation in a Conservation Effects Assessment Project watershed: Northwest Arkansas" describes the detailed methodology the project team used to correctly identify land use changes by combining image analysis with ground verification (Gitau et al. 2010). Pasture areas decreased by as much as $14 \%$, while urban areas increased by $14 \%$, depending on the subwatershed. Land use changes greatly confound relating water quality results to conservation practice adoption.

\section{CONCLUSIONS}

Like previous watershed projects, such as the Rural Clean Water Program and the USEPA Section 319 National Nonpoint Source Monitoring Program, designed to relate water quality changes to land treatment, the NIFA CEAP is contributing to our knowledge of these processes. Some of the projects have demonstrated reduced pollutants or changes in the type of pollutants as a direct result of conservation practice implementation and changed cultural practices. Modeling results suggest strategies for conservation practice adoption to protect water quality, while sociological analyses indicate producer preferences for these practices. The strong results from the NIFA CEAP studies, in combination with the other CEAP initiatives, will guide USDA policy to conservation practice planning and implementation.

\section{ACKNOWLEDGEMENTS}

The author gratefully acknowledges the edits and comments from Don Meals from Ice Nine Environmental Consulting and Lisa Duriancik from USDA Natural Resources Conservation Service.

\section{REFERENCES}

Brooks, E.S., J. Boll, A.J. Snyder, K.M. Ostrowski, S.L. Kane, J.D. Wulfhorst, L.W. Van Tassel, and R. Mahler. 2010. Long-term sediment loading trends in the Paradise Creek watershed. Journal of Soil and Water Conservation 65(6):331-341. doi:10.2489/jswc.65.6.331.

Chaubey, I., L. Chiang, M.W. Gitau, and S. Mohamed. 2010. Effectiveness of best management practices in improving water quality in a pasture-dominated watershed.Journal of Soil and Water Conservation 65(6):424-437. doi:10.2489/jswc.65.6.424.

Cho, J., G. Vellidis, D.D. Bosch, R. Lowrance, and T. Strickland. 2010. Water quality effects of simulated conservation practice scenarios in the Little River Experimental watershed. Journal of Soil and Water Conservation 65(6):463-473. doi:10.2489/jswc.65.6.463.

Duriancik, L.F., D. Bucks, J.P. Dobrowolski, T. Drewes, S.D. Eckles, L. Jolly, R.L. Kellogg, D. Lund, J.R. Makuch, M.P. O’Neill, C.A. Rewa, M.R Walbridge, R. Parry, M.A. Weltz. 2008. The first five years of the Conservation Effects Assessment Project. Journal of Soil and Water Conservation 63(6):185A-197A. doi:10.2489/jswc.63.6.185A.

Flores-Lopez, F., Z.M. Easton, and T.S. Steenhuis. 2010. A multivariate analysis of covariance to determine the effects of near-stream best management practices on nitrogen and phosphorus concentrations on a dairy farm in the New York Conservation Effects Assessment Project watershed. Journal of Soil and Water Conservation 65(6): 438-449. doi:10.2489/jswc.65.6.438.

Gale, J.A., D.E. Line, D.L. Osmond, S.W. Coffey, J Spooner, J.A. Arnold, T.J. Hoban, and R.C. Wimberley. 1993.Evaluation of the Experimental Rural Clean Water Program. National Water Quality Evaluation Project. EPA-841-R-93-005. Raleigh, NC: North Carolina State University, Biological and Agricultural Engineering Department, North Carolina State University Water Quality Group.

Gassman, P.W., J.A. Tisl, E.A. Palas, C.L. Fields, T.M. Isenhart, K.E. Schilling, C.F. Wolter, L.S. Seigley, and M.J. Helmers. 2010. Conservation practice establishment in two northeast Iowa watersheds: Strategies, water quality implications, and lessons learned. Journal of Soil and Water Conservation 65(6):381-392. doi:10.2489/jswc.65.6.381.

Gitau, M.W., I. Chaubey, E. Gbur, J.H. Pennington, B. Gorham. 2010. Impacts of land-use change and best management practice implementation in a Conservation Effects Assessment Project watershed: Northwest Arkansas. Journal of Soil and Water Conservation 65(6):353-368. doi:10.2489/jswc.65.6.353.

Jackson-Smith, D.B., M. Halling, E. de la Hoz, J.P. McEvoy, and J.S. Horsburgh. 2010. Measuring conservation program best management practice implementation and maintenance at the watershed scale. Journal of Soil and Water Conservation 65(6):413-423. doi:10.2489/jswc.65.6.413.

Jha, M.K., K.E. Schilling, P.W. Gassman, and C.F. Wolter. 2010. Targeting land-use change for nitrate-nitrogen load reductions in an agricultural watershed.Journal of Soil and Water Conservation 65(6):342-352. doi:10.2489/jswc.65.6.342.

Maresch, W., M.R. Walbridge, and D. Kugler. 2008 Enhancing conservation on agricultural landscapes: A new direction for the Conservation Effects Assessment Project. Journal of Soil and Water Conservation 63(6):198A-203A doi:10.2489/jswc.63.6.198A.

Meals, D.W., J.D Sutton, and R.H. Griggs. 1996 Assessment of progress of USDA Water Quality Projects. NQWEP Notes: 80. Raleigh, NC. http://www.bae.ncsu.edu/programs/extension/ wqg/issues/80.html.

Mudgal, A., S.H. Anderson, C. Baffaut, N.R Kitchen, and E.J Sadler. 2010. Effects of long-term soil and crop management on soil hydraulic properties for claypan soils. Journal of Soil and Water Conservation 65(6):393-403 doi:10.2489/jswc.65.6.393.

NWQEP (National Water Quality Evaluation Project) at North Carolina State University and Harbridge House Inc. 1983. The Model Implementation Program, Lessons Learned from Agricultural Water Quality Projects. USEPA 000-R-83-101. http://nepis.epa.gov/.

Rabotyagov, S.S., M.K. Jha, and T. Campbell. 2010 Impact of crop rotations on optimal selection of conservation practices for water quality protection. Journal of Soil and Water Conservation 65(6):369-380. doi:10.2489/jswc.65.6.369.

Richards, R.P., D.B. Baker, J.P. Crumrine, and A.M. Stearns. 2010. Unusually large loads in 2007 from the Maumee and Sandusky Rivers, tributaries to 
Lake Erie. Journal of Soil and Water Conservation 65(6):450-462. doi:10.2489/jswc.65.6.450.

Spooner, J., L.A. Szpir, D.E. Line, D.L. Osmond, D.W. Meals, and G.L. Grabow. 2009 Summary Report: Section 319 National Monitoring Program Projects, National Nonpoint Source Watershed Project Studies. Raleigh, NC: North Carolina State University, Biological and Agricultural Engineering Department, North Carolina State University Water Quality Group. http:// www.bae.ncsu.edu/programs/extension/wqg/ 319monitoring/09rept319/index.htm.

Tosakana, N.S.P., L.W. Van Tassell, J.D. Wulfhorst, J. Boll, R. Mahler, E.S. Brooks, and S. Kane. 2010. Determinants of the adoption of conser- vation practices by farmers in the Northwest Wheat and Range Region. Journal of Soil and Water Conservation 65(6):404-412. doi:10.2489/jswc.65.6.404.

USDA NIFA (National Institute of Food and Agriculture). 2010. NIFA Competitive Grant Watershed Studies. http://www.nrcs.usda.gov/ technical/nri/ceap/csrees.html.

USEPA (US Environmental Protection Agency). 1977. Environmental impact of land use on water quality: Final report on the Black Creek Project (technical report). EPA-905/9-77-007-B. U.S. Environmental Protection Agency, Great Lakes National Program Office. http://nepis.epa.gov/ Exe/ZyPURL.cgi?Dockey=200066HJ.txt. 